\title{
ACRL candidates for 1993 elections
}

Be sure to vote in the election

this spring

$\mathbf{T}$ he listing for each of the candidates includes their title, institution, and institutional address.

\section{Vice-President/President-Elect}

Michael D. Kathman, Director of Libraries and Media, Alcuin Library, St. John's University, Clemens Library, College of St. Benedict, Collegeville, MN 56321; Susan K. Martin, University Librarian, Georgetown University, Lauinger Library, Administrative Office, Washington, DC 20057-1006.

\section{Board of Directors}

Director-at-Large: Frances J. Maloy, Head, Circulation and Access Services, General Libraries, Emory University, Atlanta, GA 30322; Elizabeth W. Kaschins, Senior Reference Librarian, Preus Library, Luther College, Decorah, IA 52101-1039.

Director-at-Large: Rosemary Henderson, Director, Learning Resource Center, Coffeyville Community College, 11th and Willow, Coffeyville, KS 67337; Paul Dumont, Director of Technical Services, Dallas County Community College, 4343 N. Highway 67, Mesquite, TX 75150 .

\section{Afro-American Studies Librarian Section (AFAS)}

Vice-Chair/Chair-Elect: Theresa Byrd, Learning Resource Center Director, J. Sargeant Reynolds Community College, Richmond, VA 23261-2040; Michael Walker, Reference Librarian and Reference Services Automation Coordinator, Cabell Library, Virginia Commonwealth University, Richmond, VA 23284.

Secretary: Gladys Smiley Bell, Assistant Professor in the Department of Library Administration \& Coordinator, Computerized Informa- tion Services, Kent State University, Kent, $\mathrm{OH}$ 44242-0001; Delores McCoy, Head Librarian, Florida State University, Tallahassee, FL 32306; Clarence Toomer, Director of Library Services, Greensboro College, Greensboro, NC 27455.

\section{Anthropology and Sociology Section (ANSS)}

Vice-Chair/Chair-Elect: Margaret $R$. Dittemore, Social Sciences Bibliographer, University of Pennsylvania Libraries, Van Pelt-Dietrich Library Center, 3420 Walnut St., Philadelphia, PA 19104-6206; Fred J. Hay, Reference and Acquisitions Librarian, Tozzer Library, 21 Divinity Ave., Harvard University, Cambridge, MA 021382019.

Secretary: Angela S. W. Lee, Reference/Collection Development Librarian, Washington State University, Holland Library, Pullman, WA 991645610; James W. Williams, Assistant Education and Social Science Librarian, 1408 W. Gregory Dr., University of Illinois at Urbana-Champaign, Urbana, IL 61801.

Member-at-Large: Jean Shaw Adelman, Head Librarian, University Museum, University of Pennsylvania, 33rd and Spruce St., Philadelphia, PA 19104-6324; Janita A. Jobe, Government Publications Librarian, University of Nevada-Reno, Nobel H. Getchell Library, Reno, NV 89557.

\section{Arts Section (ARTS)}

Vice-Chair/Chair-Elect: Elizabeth A. Ginno, Senior Assistant Librarian, California State University, Hayward, University Library, Hayward, CA 94542; Lynn B. Williams, Humanities Reference Librarian, Auburn University Libraries, Ralph Brown Draughon Library, Auburn, AL 36849-5606.

Secretary: Henry J. DuBois, Acting Associate Director, California State University-Long Beach, University Library \& Learning Resources, 1250 Bellflower Blvd., Long Beach, CA 90840-0001; Kimberly A. Hale, Acquisitions/Serials Librarian, Columbia College, 600 S. Michigan Avenue, Chicago, IL 60605. 


\section{Asian and African Section (AAS)}

Names of candidates are not available at this time. For more information contact AAS chair Ray P. Boylan, Center for Research Libraries, 6050 S. Kenwood Ave., Chicago, IL 60637.

\section{Bibliographic Instruction Section (BIS)}

Vice-Chair/Chair-Elect: Katberine A. Branch, Head, Science Libraries, Yale University, Kline Science Library, 219 Prospect Street, New Haven, CT 06511; Randall B. Hensley, Assistant Head, Odegaard Undergraduate Library, University of Washington Libraries, OUGL DF-10, Seattle, WA 98195.

Secretary: Trudi E. Jacobson, Bibliographic Instruction Coordinator, University at Albany, State University of New York, University Libraries, 1400 Washington Avenue, Albany, NY 12222-0001; Natalie C. Pelster, Reference Librarian, Northwestern University Library, Reference Department, 1935 Sheridan Road, Evanston, IL 60208-2300.

Member-at-Large: Susan J. Hoffman, Reference Librarian, University of Minnesota, 180 Wilson Library, Minneapolis, MN 55455; Shirley R. Black Cody, Education Librarian, Grand Valley State University, Allendale, MI 49401-0000

\section{College Libraries Section (CLS)}

Vice-Chair/Chair-Elect: Victoria L. Hanawalt, College Librarian, Reed College Library, 3203 S.E. Woodstock Boulevard, Portland, OR 97202; Susan McCartby Campbell, Library Director, York College of Pennsylvania, Schmidt Library, York, PA 17405-7199.

Secretary: Stephanie R. Bangert, Library Director, Saint Mary's College of California, P.O. Box 4290, Moraga, CA 94575; Walter D. Morrill, Director of Libraries, Hanover College, Duggan Library, P.O. Box 287, Hanover, IN 47243-0287. Member-at-Large: Mark G. R. McManus, Assistant Director/Systems Librarian, Simpson Library, Mary Washington College, 1801 College Ave., Fredericksburg, VA 22401-4664; Norma N. Yueb, Executive Officer of the Center for Intercultural Education/Professor for Library Science, 505 Ramapo College of New Jersey, Ramapo Valley Road, Mahwah, NJ 07430-1623.

\section{Community and Junior College Libraries Section (CJCLS)}

Vice-Chair/Chair-Elect: Susan M. Maltese, Cataloging Librarian, Oakton Community College, 1600 East Golf Road, Des Plaines, IL 600161258; William J. Pfannenstiel, Librarian, North- eastern Oklahoma A\&M College, Learning Resources Center, 200 I N.E., Miami, OK 74354. Secretary: Rita W. Jones, Dean, Library Services, City College of San Francisco, 50 Phelan Avenue, San Francisco, CA 94112-1821; Karl B. Jobnson, Library Director, East Campus, Pima Community College, 8202 E. Poincina, Tucson, AZ 85730.

\section{Education and Behavioral Sciences Section (EBSS)}

Names of candidates are not available at this time. For more information contact EBSS chair Jo Ann Carr, Director, IMC, University of Wisconsin, 225 N. Mills, Madison, WI 53706.

\section{Extended Campus Library Services Section (ECLSS)}

Vice-Chair/Chair-Elect: Guendolyn J. Chandler, Chair, Open Campus Library Services, Florida Community College at Jacksonville, Downtown Campus Learning Resources Center, 101 W. State St., Jacksonville, FL 322023089; Katbleen M. O'Connor, Coordinator, Offcampus Library Services, Gonzaga University, Crosby Library, E. 502 Boone, Spokane, WA 99258-0001.

Secretary: Mem Catania, Librarian, University of Central Florida-Brevard, 1519 Clearlake Road, Cocoa, FL 32922-6597; Virginia A. Witucke, Offcampus Librarian, Central Michigan University, 8550 Lee Highway, Fairfax, VA 22031-1515.

Member-at-Large: Thomas E. Abbott, Director of Learning Resources, University of Maine at Augusta, Augusta, ME 04330; Monica H. Collier, Off-campus Librarian, Central Michigan University, 755 W. Big Beaver, Suite 222, Troy, MI 48084-4903.

\section{Low and Political Science Section (LPSS)}

Vice-Chair/Chair-Elect: Ronald J. Heckart, Librarian, Institute of Governmental Studies Library, University of California, Berkeley, IGS Library, 109 Moses Hall, Berkeley, CA 94720; Judy L. Solberg, Social Sciences Bibliographer, University of Maryland Libraries, College Park, MD 20742-7011.

Secretary: Marifran Bustion, Head, Acquisitions Department, George Washington University, Gelman Library, 2130 H. St. N.W., Washington, DC 20052-0001; William A. Orme, Bibliographic Instruction Coordinator, University Library, Indiana University-Purdue University at Indianapolis, Indianapolis, IN 46202.

Member-at-Large: Grabam $R$. Walden, Assis- 
tant Professor and Reference Librarian, Ohio State University Libraries, 126 Main Library, 1858 Neil Avenue Mall, Columbus, OH 43210; Stephen J. Stillwell Jr., Librarian, Center for Science and International Affairs Library, Harvard University, 79 John F. Kennedy Street, Cambridge, MA 02138.

\section{Rare Books and Manuscripts Section (RBMS)}

Vice-Chair/Chair-Elect: Lisa Browar, Assistant Director for Rare Books and Manuscripts, The New York Public Library, 5th Avenue \& 42nd Street, New York, NY 10018-2788; Robert Martin, Assistant Director of Libraries for Special Collections, Louisiana State University Libraries, Baton Rouge, LA 70803.

Secretary: Martin Antonetti, Librarian, The Grolier Club Library, 47 East 60th Street, New York, NY 10022-1005; Laura Stalker, Assistant Director of the Center for Bibliographic Study, ESTC/NA and the University of California-Riverside, Riverside, CA 92517-5900.

Member-at-Large: Thomas Hickerson, Director of Rare Book and Manuscript Collections, Cornell University, Ithaca, NY 14853; John Hoover, Head, Special Collections/Rare Books Librarian, Saint Louis Mercantile Library, 510 Locust Street, 6th Floor, St. Louis, MO 631011845.

\section{Science and Technology Section (STS)}

Vice-Chair/Chair-Elect: Caroline D. Harnly, Physical \& Applied Sciences Subject Specialist and Reference Services Coordinator, San Francisco State University, J. Paul Leonard Library, 1630 Holloway Avenue, San Francisco, CA 94132-1722; Katharine E. Clark, Head, Life Sciences Library, Penn State University, E205 Pattee Library, University Park, PA 16802.

Secretary/Member-at-Large: Dolores (Dee) $M$. Hoelle, Engineering Librarian, Princeton University, Engineering Library, Princeton, NJ 08544; Billie Joy Reinbart, Science \& Engineering Librarian, Cleveland State University, 1860 East 22nd Street, Cleveland, OH 44114-4435.

\section{Slavic and East European Section (SEES)}

Vice-Chair/Chair-Elect: Alan P. Pollard, Head, Slavic \& East European Division, Hatcher Graduate Library, University of Michigan, Ann Arbor, MI 48109.

Secretary: Janet I. Crayne, Slavic Cataloger and Acting Slavic Bibliographer, Alderman Library, University of Virginia, Charlottesville, VA 22903
2498; Mieczyslaw Buczkowski, Assistant Professor/Slavic Bibliographer, University of Colorado, Norlin Library, Campus Box 184, Boulder, CO 80309-0184.

Member-at-Large: Nina Palmin, Slavic Cataloger, Library of Congress, 101 Independence Avenue, S.E., Washington, DC 20540-5530; Patricia K. Thurston, Bibliographer/Library Assistant II, Center for Soviet and East European Studies, University of Texas at Austin, Austin, TX 78713 .

\section{University Libraries Section (ULS)}

Vice-Chair/Chair-Elect: Nancy L. Baker, Director of Libraries, Washington State University, Pullman, WA 99164-5610; Josepb A. Boissé, University Librarian, University of California, Santa Barbara, Santa Barbara, CA 93106.

Secretary: Suzette L. Radford, Access Services Librarian, University of Washington, OUGL DF10, Seattle, WA 98195; Doris Hayashikawa, Head, Cataloging Department, University of Pittsburgh, Hillman Library, Pittsburgh, PA 15260.

Member-at-Large: E. Dale Cluff, Director of Libraries, University Library, Texas Tech University, Lubbock, TX 79409-0002; Carolyn Dusenbury, Director of Library Services, Meriam Library, California State University-Chico, Chico, CA 95929-0295.

Member-at-Large: Karen S. Seibert, 1724 E. Woodward \#203, Austin, TX 78741-7851; Jobn William Collins III, Librarian of the Graduate School of Education, Harvard University, Gutman Library, 6 Appian Way, Cambridge, MA 02138 .

\section{Western European Specialists Section (WESS)}

Vice-Chair/Chair-Elect: Thomas D. Kilton, Assistant Modern Languages \& Linguistics Librarian, University of Illinois Library - 425, 1408 West Gregory Drive, Urbana, IL 61801; Jobn M. Cullars, Bibliographer for the Humanities, University of Illinois at Chicago, University Libraries, P.O. Box 8198, Chicago, IL 60680-8198.

Secretary: Blake Landor, Classics, Philosophy, and Religion Bibliographer, George A. Smathers Libraries, University of Florida, 140 Library West, Gainesville, FL 32611; Heidi L. Hutchinson, Cataloger and Selector for German and Russian Programs, University of California, Riverside, Rivera Library, P.O. Box 5900, Riverside, CA 92517.

Member-at-Large: $W$. David Rozkuszka, For- 
eign \& International Documents Librarian/African \& Middle Eastern Bibliographer, Stanford University Libraries, Stanford, CA 94305-6100; Gretchen E. Holten, Humanities/Social Sciences Bibliographer, University of Nebraska-Lincoln, 216N Love Library, Lincoln, NE 68588-0410.

\section{Women's Studies Section (WSS)}

Vice-Chair/Chair-Elect: Cyntbia S. Faries, Reference Librarian, Penn State University, E108 Pattee Library, University Park, PA 16802; Lori A. Goetsch, Head, Information/Reference, Michigan State University Libraries, East Lansing, MI 48824-1048.
Secretary: Thura Reed Mack, Reference Librarian, University of Tennessee, Knoxville, TN 37996-1000; Grace M. Jackson-Brown, AfroAmerican Studies Subject Specialist and Branch Head Librarian of the Black Culture Center Library, Indiana University-Bloomington, Black Culture Center Library, 109 N. Jordan Ave., Bloomington, IN 47405.

Member-at-Large: Mila C. Su, Senior Assistant Librarian-Reference, Robert E. Eiche Library, Penn State Altoona Campus, Altoona, PA 16001; Kristin H. Gerbard, Authorities Coordinator and Monographic Cataloger, Iowa State University, 204 Parks Library, Ames, IA 50011.

\section{(Scan cont. from page 24)}

James L. Morrison, "Establishing an environmental scanning/forecasting system to augment college and university planning," Planning for Higher Education 15(1) (1987): 7-22.

Mark Sandler, "Dollar watch: 1991 year-end update," Library Lssues 12(3) (January 1992): 2-3.

Mimi Harris Steadman and Ralph A. Wolff, Evaluating Library Quality in the Accreditation Process: What Changes Do New Technologies Bring? Unpublished discussion paper for the Accrediting Commission for Senior Colleges and Universities and the WASC Presidents' Forum, 1991.

Marvin J. Cetron and Owen Davies, "Fifty trends shaping the world," The Futurist 25(5) (September-October 1991): 12-21.
Visions Listserv postings, 4/92-6/92.

The Winds of Change: Key Trends Impacting Associations in the '90s. Unpublished 1991 draft prepared by the American Society of Association Executives.

Strategic Planning Documents from various university libraries were also consulted and many conversations with library educators were held. A special thanks to all the institutions who responded to William Pfannenstiel's survey updating the ACRL Environmental Scan.

Autbors'note: We would like to thank all the members of the ACRL Planning Committee for assistance provided in preparing this scan.

\section{Operate an ERIC clearinghouse}

The U. S. Department of Education announces a competition (Request for Proposals-RFP) for the award of 16 contracts to operate Educational Resources Information Center (ERIC) Clearinghouses.

Located around the country, the 16 ERIC Clearinghouses-the subject of this RFP-are each responsible for acquiring, processing, synthesizing, and disseminating information about particular aspects or subject areas of education. Established in 1966, ERIC is a national information network designed to provide users with ready access to education materials.

A separate contract will be issued for each ERIC Clearinghouse, as follows: Adult, Career, and Vocational Education; Assessment and Evaluation, Community Colleges; Counseling and Student Services, Disabilities and Gifted Education; Educational Management; Elementary and Early Childhood Education; Higher Education; Information Resources; Languages and Linguistics; Reading and Communication Skills; Rural Education and Small Schools; Science, Mathematics, and Environmental Education; Social Studies/Social Science Education; Teaching and Teaching Education; and Urban Education.

Proposals are due January 29, 1993. Send proposals to: LaTonya D. Simpson, Grants and Contracts Service, GSA Building, Room 3633, 7 th and D Streets, SW, Washington, D.C. 20202; phone: (202) 708-8191. 